\title{
The Last Swiddens of Sarawak, Malaysia
}

\author{
Ole Mertz • Kelvin Egay • Thilde Bech Bruun • \\ Tina Svan Colding
}

Published online: 29 December 2012

(C) Springer Science+Business Media New York 2012

\begin{abstract}
Swidden cultivation was observed to be under pressure but still persisting in many areas in Sarawak, Malaysia around 2000-2003. Since then rapid development of smallholder oil palm and rubber, continuing urbanization and rural to urban migration appear to have considerably reduced the area under swidden cultivation. With the aim of understanding the extent and impacts of this development, 55 households in three communities that were interviewed in 2002-2003 were re-interviewed in 2011. In an area with rapid oil palm development, the households engaged in smallholder oil palm production have experienced considerable improvements in income and wealth whereas the other households have experienced more limited wealth increases or even a decline in income. Many households have decreased or abandoned cultivation of upland rice, which used to be the core of the swidden cultivation system,
\end{abstract}

O. Mertz $(\bowtie)$

Department of Geosciences and Natural Resource Management, University of Copenhagen, Øster Voldgade 10,

1350 Copenhagen, Denmark

e-mail: om@geo.ku.dk

\section{K. Egay}

Faculty of Social Sciences, Universiti

Malaysia Sarawak, Kota Samarahan,

Sarawak, Malaysia

e-mail: jkegay@fss.unimas.my

\section{T. B. Bruun}

Department of Plant and Environmental Sciences,

University of Copenhagen, Thorvaldsensvej 40,

1871 Frederiksberg, Denmark

e-mail: thbb@life.ku.dk

\section{T. S. Colding}

National Survey and Cadastre, Rentemestervej 8,

2400 Copenhagen, NV, Denmark

e-mail: tisha@kms.dk and the upland soils in the area are now dominated by oil palm. In another area, where no oil palm development has taken place because of a hydroelectric dam, upland rice fields under swidden cultivation have also decreased and new high yielding rubber is now being planted because of the favorable rubber prices. Moreover, tourism has in this area gained further economic importance and overtaken agriculture as the main economic activity of households. The demise of swidden has not yet occurred in Sarawak, but a continued decline has been observed. However, there is a possibility that the new smallholder oil palm and rubber may provide an opportunity for a new type of 'productive fallow' that will allow continued cultivation of upland rice on a small scale.

Keywords Land use change $\cdot$ Livelihoods $\cdot$ Malaysia $\cdot$ Oil palm $\cdot$ Shifting cultivation $\cdot$ Smallholders $\cdot$ Southeast Asia

\section{Introduction}

The possible demise of swidden cultivation in Southeast Asia was assessed by Padoch et al. (2007) and the majority of cases reviewed did indeed show strong signs of swidden cultivation disappearing in many areas, particularly in mainland Southeast Asia. This was confirmed later by a study focusing on changes in swidden cultivation globally, but here it was also revealed that this farming system still exists and thrives in many parts of the world (van Vliet et al. 2012). In both studies, the cases reviewed from Borneo showed that upland rice cultivation under swidden still persisted in many areas, but that the rapid economic development and land policies in both Malaysia and Indonesia were putting increasing pressure on the system, especially from large scale and smallholder plantation development. 